\title{
Should the Smartphone Be Considered an ICT?
}

\author{
Casanova-del-Angel Francisco \\ Instituto Politécnico Nacional, ESIA Unit ALM, Mexico City, Mexico \\ Email: fcasanova@ipn.mx
}

How to cite this paper: Francisco, C.-del-A. (2021) Should the Smartphone Be Considered an ICT?. Open Journal of Statistics, 11, 539-557.

https://doi.org/10.4236/ojs.2021.114034

Received: May 27, 2021

Accepted: August 20, 2021

Published: August 23, 2021

Copyright (c) 2021 by author(s) and Scientific Research Publishing Inc. This work is licensed under the Creative Commons Attribution International License (CC BY 4.0).

http://creativecommons.org/licenses/by/4.0/

\begin{abstract}
This article looks at a didactic experience at the undergraduate level in civil engineering, specifically, teaching a mathematics course through smartphones. The objective was to teach a course of an engineering degree primarily using this technology, in order to promote among the students their skills and competencies to develop and present a theme. It should be mentioned that every student in this case study used his/her knowledge at unusual hours, that is, 1 a.m. or 2 a.m., sharing their work with me or asking me for academic help to solve a specific problem. This adaptation process in teaching practice is not easy and may not be achieved in a short period of time. The principal idea to highlight is that planning activities with new technologies cannot be carried out spontaneously and must be based on an educational model. Another important thing in this type of courses is the assessment of the teacher, priority of education administrators. Based on a questionnaire distributed to the students upon conclusion of the course, a statistic and probabilities analysis was carried out, showing surprising results regarding the questions-Did you like the course? What did you not like about the course? And What would you change about the course?
\end{abstract}

\section{Keywords}

Smartphone, ICT(s), Skills, Competencies, Civil Engineering

\section{Introduction}

Long after the invention of writing, the first steps towards an information society were marked by the telegraph, then by the telephone and TV and now by the Internet and the bandwidth. Text, words and pictures are already relayed by mobile phones and GPS. Nowadays, the Internet and TV may be accessed through mobile phones, which also have their own photo camera. Computer science and telecommunications have benefited from miniaturization of components, which has allowed the production of devices at affordable prices. The 
use of ICTs (Information Communications Technologies) continues to increase and expand, above all, in rich countries, therefore widening the digital, social, and generational gaps.

For a long time, educational authorities throughout the world have been pushing technological innovation. They demand that the so-called Information and Communications Technologies (ICTs) be used in class, whether the teachers are prepared to do so and/or whether the facilities are suitable or not. Upon such request, the first question a teacher has to ask himself/herself is: What does ICT mean? Let us briefly review an answer.

Information and Communications Technologies (ICTs) are technologies used to manage data and send it from one place to another. They cover a wide range of application; they can store, recover, send, receive, and process data in order to obtain results, prepare reports, come to conclusions, and tailor actions. ICTs are conceived as the universe of two sets, represented by the traditional Communication Technologies (TCs), which mainly include radio, TV, and conventional telephony, and Information Technologies (ITs); characterized by digitalization of technologies to record contents: computing, communications, telematics, and interfaces. They may be considered as dynamic, since at the end of the nineteenth century, the phone, in accordance with the current definitions, was considered a new technology, but the term and concept did not exist yet. The same consideration could be applied to TV when it appeared and became popular in the 1950s. Looked at broadly, it may be considered that the new technological developments applied to the phone, TV, and computer are part of ICTs, which favor communication and data exchange in the current world [1].

Nowadays, no one is surprised to be well informed every minute, to communicate with people on the other side of the world, to watch a music video or to work in teams in discrete locations. With an unthinkable quickness, ICTs are increasingly becoming an integral of contemporary life. This phenomenon, also called the information society, is mainly due to a computer development which started to be formed four decades ago: The Internet. It was created as part of the Advanced Research Projects Agency Network, created by the Department of Defense of the US to communicate the various bodies within the country. Its main purposes were: to be a de-centralized network with multiple ways between two points and the messages could be divided in parts, which would be sent by different ways. The presence of several universities and institutes in the development of the project allowed to find many possibilities of exchanging data. E-mail, messenger and web pages were created. But it was not until the middle of the 90s of the Twentieth Century, when it was not a military project any more, that the real explosion of the Internet came, together with everything we now know as ICTs [2].

The development of the Internet has enabled data to be available in many places at the same time (whether this is for good or not, I do not know). Before, data was concentrated; it was given by parents, teachers, books, and friends. Knowledge was concentrated in schools and universities. Now, with the Internet 
there is more access to information. The principal problem is the quality of such information. Contact between people and those ding businesses has become more agile. It is not necessary to move in order to close businesses in a different city in the world or to make transactions in any place with a simple click [1] [3] [4].

As for education, particularly that offered in Mexico, objectives, goals, pedagogies and didactics must be reformulated. The same technological forces making possible new ways to learn, will have to make learning agreeable and practical. Schools must reinvent themselves around the opportunities opened by the information technology; and this is not happening. Virtual educational networks must transform themselves into the new basic units in the educational system, including design and construction of new educational scenarios; preparation of electronic educational instruments; and training of teachers specialized in teaching in a new social space.

ICTs are theoretical-conceptual tools; supports and channels processing, storing, synthesizing, recovering and presenting information in various ways. Supports have evolved throughout the last years: optical telegraph, fixed telephone, cell phones, TV, computer, Internet, and wide band. The use of ICTs represents an outstanding variation in the behavior of society and a change in education and interpersonal relationships, since the way to spread and generate knowledge has changed [5] [6].

The above paragraphs do not show the educational institutions anywhere in the world in a good light. Expose them! Particularly, the National Polytechnic Institute (NPI), since the provision and use of ICTs (as we have defined them) in a classroom are beyond the institution's capabilities. Why? Because even while some universities in the world may have some of those technological supports: are teachers prepared to use them for academic purposes? I don't know! The NPI has itself all those technological resources: TV channel, radio, its own telephone network, facilities, laboratories, and first world workshops, but its administrative authorities have not encouraged professors to use them. For this reason, I have asked myself, for several years, questions without any apparent answer, such as: How can we create a course at a bachelor level through a cell phone if students must attend school? Would this type of course minimize the current attending teaching model and would the non-attending model develop? Should a hybrid educational model be created? We must not forget that the IPN also has non-attending study plans. Moreover, how would the labor relationship be if teachers would not need to attend their classrooms or offices every day anymore?

Based on the fact that students use non-elementary functions of their cell phones, I asked myself: Would a Smartphone be useful in a mathematics, physics or structural dynamics course? Would something like that be useful in their professional life? To this, an additional complicating element must be added: since 2003, the NPI has adopted an educational model based on two pedagogical 
concepts known as competencies and skills [7]. At first, no one objected to it, but upon trying to implement it, the main question among advanced teachers was: How do I teach engineering knowledge making the student competent to show his/her skills if he/she cannot show his/her skills (if he/she has some) since he/she does not have knowledge? [8]. The following objective of this project is based on such premise.

\section{Dissertation on the Content}

Literature on the topic shows there are various approaches on the study of Smartphone in education. Researches range from basic education to post-graduate studies. For instance, in [9] the study found a positive usefulness of the use of smartphone in the students learning activities such as easy sharing and accessing of lecture materials online, easy communication with colleagues and course masters, being able to carry smartphone any anywhere and at any time because of its portability as compared to a laptop and many others. Again, the study revealed negative effect on students' academic activities by the use of smartphones whereby, for instance, smartphones shift the focus of users because of its addictive nature, intruding calls coming in during lecture hours and the tendency of checking social media platform which distract learning on the part of the distance learning students and some of the inhibiting factors found were unreliable internet connectivity, the screen and sizes make smartphone uncomfortable for learning. In [10] it is commented how teachers are bothered with students using cell phones in the classroom. Using of social media like texting, tweeting, and snap chatting during in class is an incredible disruption, resulting in a difficult education environment. In this article, we propose an innovative approach to encourage students to use their smartphone effectively in classroom and we evaluate our approach in terms of students' performance and materials retention. In [11] a phenomenological study is used to know more about the phenomena that arise from the use of mobile phones, which is assumed as a device of techno-pedagogical design, but which can also represent a source of distraction. An analysis is made of the previous reports associated with the academic and personal incidences of the use of the Smartphone by students in the university. A set of analysis conditions were gathered, including advantages and disadvantages of the use of these devices in the learning processes, which seek to achieve better results related to the pedagogic interaction and meaningful learning. In [12] it is shown a study on coverage and educational uses of the cell phone comprising students and teachers from two campuses of the Autonomous University of Baja California. It is based on a random sample with $12 \%$ students and $24 \%$ teachers to whom a survey was applied in order to specify the possession of a cell phone, their technical features, educational uses performed and advantages and disadvantages of its use in university courses. The possession of a cell phone is close to $97 \%$ for both students and teachers. The main educational uses were: communication, data management and organization. Disadvantages were, among 
others, distraction and high connection costs. The advantages mostly mentioned were the positive fact of having access to communication and data at all times and places.

In the case shown here, the main idea was to understand two concepts that are already part of the educational model of this institution since 2003: competencies and skills, which are not perfectly defined in their original format. How to make students compete if they do not possess the knowledge to allow them to do so? And, above all, if they do not have certain knowledge, what kind of skills they may develop in the classroom? But these two concepts may also be applied to teachers and I cannot conceive how to study such phenomenon and its labor, academic and scientific connotations. For instance, from a scientific point of view, it might be argued that such person publishing most articles is more competent than his/her peers, but how could we analyze all the scientific garbage he/she publishes every day? From a teaching point of view, educational institutions have focused on assessing the student, but have not paid attention to the fact that if a student dislikes you as a teacher, all your efforts will be ruined.

\section{Objective}

To teach a face-to-face course at an engineering level, exclusively using an ICT in order to promote among the students the skill and competence for the development, learning and presentation of the topics in the course and that, simultaneously, the remaining students may practice the assessment technique [13].

\section{Presentation of the Course}

The course under study is a mathematics one of the civil engineering syllabus at the NPI, Mexico. Its subject has as main topic mathematical analysis for engineers. I think it is necessary to state here that it is not the first course carried out with the methodology stated in this document [13] [14].

At the beginning of the course, the conditions were presented to the students:

- Creation of a log to record everything related to the progress of each session, with the suggestion to write all the events and record personal comments. The log record responsibility would be randomly assigned, so that everybody could participate;

- No student was to enter the classroom after the specified starting time or leave the classroom before the specified ending time (it is very common at the NPI to see that student, without saying a word, get up and go out of the classroom); and

- All the students would attend the sessions with a cell phone with software such as WhatsApp, Office and Messenger (trademarks registered by their owners).

Based on the above, students were sorted into groups they had created by themselves in twos, threes, and fours. The topics of the course were assigned among the students randomly, through pieces of papers. Some personal data was 
asked of all the students, such as: postal and electronic address and personal phone number to be entered into the school network; said data would be gathered in a folder with their names, as a portfolio of evidence. Control would be made using a Smartphone, which would work as a root phone, through which the academic and administrative data would flow from and to the members of the group [15].

The principal purpose of the course, with randomly assigned topics, was that the work team would develop the topic on their PC, using a word processor. It would be sent to the teacher through the root phone, the teacher would check it, make corrections and comments, and return it. The group would make any changes and develop a Power Point presentation. Upon completion of the presentation, this would be sent to all the members of the academic network so that each of them could follow the presentation.

\subsection{About the Teacher}

One of the questions all the students make upon starting a course is about the grading method or the grades they will receive in exchange for their effort. It was established that they should grade themselves based on the following two points: 1) upon completing the presentation of the topic, pieces of paper would be distributed to write down the name of the assessing person and the name(s) of the person/people being assessed; 2) then, the students attending the session would record a personal assessing note with a number between 0 and 10 (grading values used in Mexico); according to, the grade they considered the presenters deserved. Annex 1 includes the assessment recording format for the students. Another important part of participation by the students was that, after their presentations, they should give a set of problems as homework. The students attending the presentation should solve them and return them to the presenters. The presenters should assess it, grade it, and make observations to their peers, Annex 2.

\subsection{Features and Obligations of Teams}

If a member of the class did not attend to the course when he/she was supposed to present his/her topic, the examination or topic of the course would be considered as Not Presented (NP). As a teacher, I specified that the grades given by the students would be secret and that I would record them in a special format, Annex 1, and that I would keep them to analyze them in order to avoid biases; and that, I would give another grade which I considered the presenters would deserve. Both grades would be averaged as the final grade. No grade would be subject to negotiation, neither the ones given by the students nor the ones given by myself, the teacher. Then, I would record the average grade in the official grading system of the institution (such IPN's official grading system is the School Management System, SAES in Spanish, and may be accessed from anywhere in the world). I must state here that there was a variation regarding the 
final exam for the class. I sent an exam through a Smartphone to one of the groups, which they returned to me in the same way. This was graded and the grade was given and averaged with the grade given by their peers. The other students took the traditional written exam.

\section{Methodology}

It was specified that all the topics under development should have an introduction, a theoretical part with the corresponding examples solved, and another part about engineering applications. The structure of the written work also had to include a brief conclusion, discussion or reflection on the corresponding topic (as the case required it), as well as its corresponding bibliography. The work team had the obligation to give homework on the topic presented, sending it through WhatsApp, and the remaining students had to solve it on their PC and would return it through the same way to the presenters so they could assess the work and give a grade on the homework, Annex 2.

In spite of the fact that an academic network was created, I did not deem necessary that the students should create a blog.

\section{Notes on the Development of the Course}

The course developed without significant inconveniences. All the students attended the sessions without interruptions, prepared their topics for the teacher and then presented them to their peers, giving their assessments and homework in due time and manner.

Now, one of the priorities of education administrators, for a long time, has been the assessment of the teacher by students. On this issue, I tend to differ. Why? There are several reasons worth reviewing. A person, who is still in the learning stage and under the pressure of compulsory learning, has no clear vision about assessing someone who may pass him/her or not or simply does not feel capable of evaluating the person assessing him/her. Grades given about the teacher's performance have a lot to do with student-teacher empathy that develops throughout the course (as a teacher, a student may like you or not and he/she will grade you based on such liking and not on your didactics or your knowledge). The student who does not accept his/her previous lack of knowledge on the topic blames the corresponding teacher for this. Throughout my academic life, I have developed several questionnaires to assess my performance throughout the semester. One is included in Annex 3, which I distribute among the students upon completing the course. Here there are some of the most common comments of theirs to three extra questions I ask them: What did you like about the course? What did you not like about the course? What would you change about the course?

Regarding the question What did you like about the course? Their answers ranged from "a new way to take class" to "living in limbo". I must state here the liking by some students as they were part of a project that forced them to behave 
as engineers and gain confidence [16].

As for the question What did you not like about the course? The answers have a lot to do with how seriously the student took delivering their theoretical-practical document, their bad presentations, and not taking seriously their work outside the classroom. They also felt like that it was hard work to understand, by themselves, topics that were absolutely new to them. To learn topics by themselves was a new experience and an almost unachievable challenge. But the most surprising answer was that the students that were not assessed through a traditional-style exam and felt disappointed at not facing the challenge of assessment of the real level of knowledge acquired in the classroom. They did not like to work in teams either, and complained about the lack of commitment of their peers, and their lack of previous knowledge. And, as a reflection, a couple of questions remain too difficult to confront: Do students studying an undergraduate degree in a distance mode really learn? And, upon completion of such type of studies Do they have the same quality of knowledge as the students that completed their degree in the traditional system?

Regarding the question: What would you change about the course? The answers are simple. They did not feel comfortable working with dry topics (mathematics) through a Smartphone, and they regretted not being able to use other didactic tools. As always, they asked that exercises and examples be developed on the blackboard. Therefore, the following questions arise: Are ICTs only supportive in face-to-face courses? What type of problems do students who study in distance modes face? I do not have answers for those questions, since they were not part of the objective and no work was carried out in order to answer them.

\section{Statistical Analysis of Answers to the Questionnaire}

Data analyzed comes from 51 questionnaires gathered throughout three consecutive semesters; in which this type of course was taught. The corresponding tabular structure is [17] [18]:

$$
k_{I J}=\{k(i, j) \text { such that } i \in I, j \in J\}
$$

where set $I$ represents the 13 non-free questions presented to the students and set $J$ represents the assessment ranges for each question of set $I$. No specific table of descriptive statistical parameters such as medians, variances or deviations is shown, let alone charts, mainly because what has been tried to be measured is the behavior between the theoretical and empirical accumulated distributions and their significance [19]. Statbox commercial software (trademark registered by its authors and/or developers) was used.

\section{Probabilistic Parameters of Variables under Study}

Let us now ask if the students assessing their teacher correctly give an opinion about the quality of the course they have received. In order to answer such question, data gathered through questionnaire included in Annex 3 has been analyzed. 
The uniform probability law was used because it is useful to describe a random variable with constant probability on the interval $(a, b)$ in which it is defined, denoted by $U(a, b)$. It is also known as rectangular distribution due to its density function. An important feature of this distribution is that the probability of an event exclusively depends on the width of the interval being considered and not on its position in the variable's variation field. Statistical parameters calculated per variable in all the study have been assessed for a 95\% confidence level.

Regarding the results shown in Table 1, Kolmogórov-Smirnov's D value observed has nonparametric character of the test and it will suffice that distribution of $\mathrm{D}$ does not depend on the shape of the distribution given a priori (uniform),

Table 1. Comparison of parameters estimated based on data gathered and the uniform probability law.

\begin{tabular}{|c|c|c|c|c|c|c|c|c|c|c|}
\hline & \multicolumn{2}{|c|}{ Abstention } & \multicolumn{2}{|c|}{ Low quality } & \multicolumn{2}{|c|}{ Certain quality } & \multicolumn{2}{|c|}{ Quality } & \multicolumn{2}{|c|}{ High quality } \\
\hline & Estimate & Theoretical & Estimate & Theoretical & Estimate & Theoretical & Estimate & Theoretical & Estimate & Theoretical \\
\hline Expected & 0.38 & 1.50 & 0.62 & 0.50 & 3.92 & 5.00 & 18.85 & 19.00 & 27.23 & 26.00 \\
\hline Variance & 0.76 & 0.75 & 0.26 & 0.08 & 10.08 & 8.33 & 82.97 & 65.33 & 138.03 & 120.33 \\
\hline Asymmetry & 2.08 & 0.00 & -0.42 & 0.00 & 0.28 & 0.00 & -0.04 & 0.00 & 0.14 & 0.00 \\
\hline Kurtosis & 3.36 & -1.20 & -1.96 & -1.20 & -1.31 & -1.20 & -1.46 & -1.20 & -1.21 & -1.20 \\
\hline $\begin{array}{c}\text { Kolmogorov-Smirnov } \\
\text { D-value observed }\end{array}$ & \multicolumn{2}{|c|}{0.77} & \multicolumn{2}{|r|}{0.38} & \multicolumn{2}{|c|}{0.26} & \multicolumn{2}{|r|}{0.12} & \multicolumn{2}{|r|}{0.10} \\
\hline $\mathrm{p}$ value associated & \multicolumn{2}{|c|}{$10.95 \mathrm{E}-0.8$} & \multicolumn{2}{|r|}{0.03} & \multicolumn{2}{|c|}{0.29} & \multicolumn{2}{|c|}{0.98} & \multicolumn{2}{|r|}{1.00} \\
\hline
\end{tabular}

The difference between The difference between The difference between The difference between The difference between

\begin{tabular}{|c|c|c|c|c|c|}
\hline & empirical & empirical & empirical & empirical & $\begin{array}{c}\text { empirical } \\
\text { and theoretical }\end{array}$ \\
\hline \multirow[t]{4}{*}{ Conclusion } & accumulated & accumulated & accumulated & accumulated & accumulated \\
\hline & distributions is & distributions is & distributions is & distributions is & distributions is \\
\hline & significant for & significant for & significant for & significant for & significant for \\
\hline & Alpha $=0.05$ & Alpha $=0.05$ & Alpha $=0.05$ & Alpha $=0.05$ & Alpha $=0.05$ \\
\hline
\end{tabular}

Conformity test Khi2 between observed and theoretical effectives

\begin{tabular}{|c|c|c|c|c|c|}
\hline $\begin{array}{c}\text { Khi2 value observed } \\
\text { with } \mathrm{ddl}=17\end{array}$ & 148.54 & 123.92 & 22.38 & 13.15 & 13.15 \\
\hline $\mathrm{p}$ value associated & 0.00 & 0.00 & 0.17 & 0.73 & 0.73 \\
\hline \multicolumn{6}{|c|}{ Conformity test Khi2 between observed and theoretical effectives } \\
\hline $\begin{array}{l}\text { Khi2 value observed } \\
\text { with ddl }=16\end{array}$ & 14.04 & 40.81 & 19.58 & 10.35 & 10.35 \\
\hline $\mathrm{p}$ value associated & 0.60 & $5.92 \mathrm{E}-04$ & 0.24 & 0.85 & 0.85 \\
\hline Conclusion & $\begin{array}{c}\text { Conformity is not } \\
\text { significant }\end{array}$ & $\begin{array}{c}\text { Conformity is } \\
\text { significant }\end{array}$ & $\begin{array}{c}\text { Conformity is not } \\
\text { significant }\end{array}$ & $\begin{array}{c}\text { Conformity is not } \\
\text { significant }\end{array}$ & $\begin{array}{c}\text { Conformity is not } \\
\text { significant }\end{array}$ \\
\hline
\end{tabular}

Notes: The critical value for the Khi2 conformity test between observed and theoretical effectives is equal to 27.58 for all cases and 26.29 for kh2 conformity test without the strongest contribution. 
but the fact that the values of the sample follow the law. This shows that the value only depends on the n-realizations of the uniform random variable; that is, the relationship between the abstention questions and poor-quality shows low relevance in the correct opinion on the quality of the course. Now, since $\mathrm{Khi}^{2}$ assesses, in a way, the distance between observation and the null hypothesis corresponding to the multinomial scheme, the conclusion of conformity regarding the low quality of the course is significant, that is, there is a disagreement between the low quality of the course and the correct opinion about the quality of it. The above may also mean that those who gave this grade to the course are in irreverent status.

Despite the fact that it is always asked to show only the conformity tests, without the strongest contribution, I wanted to show both calculations in order that a comparison can be made between them and to show that, in effect, the grades given to the low quality of the course and abstention of an opinion, whether in favor or not, strongly contribute to the kurtosis of the distribution.

As for the correlation coefficients obtained from the four types of analysis in principal components, ACP, shown in Table 2, significant correlations are shown in bold letters. It may be easily observed that the distance used does not matter, whether it is Pearson's, Spearman's or Kendall's, since the same relationships are notable, but with different values. Responses given to the low quality of the course are evidenced against certain quality and high quality. On the other hand, the remaining qualities of the course are grouped, see Figures 1(a)-(c). Finally, the covariance matrix is correctly expressed.

Let us now see the multidimensional analysis of data under study [13] [20] [21]. Based on the basic purpose not to confound the reader, in Table 2 I present the results of the analysis organized into principal components, ACP, from

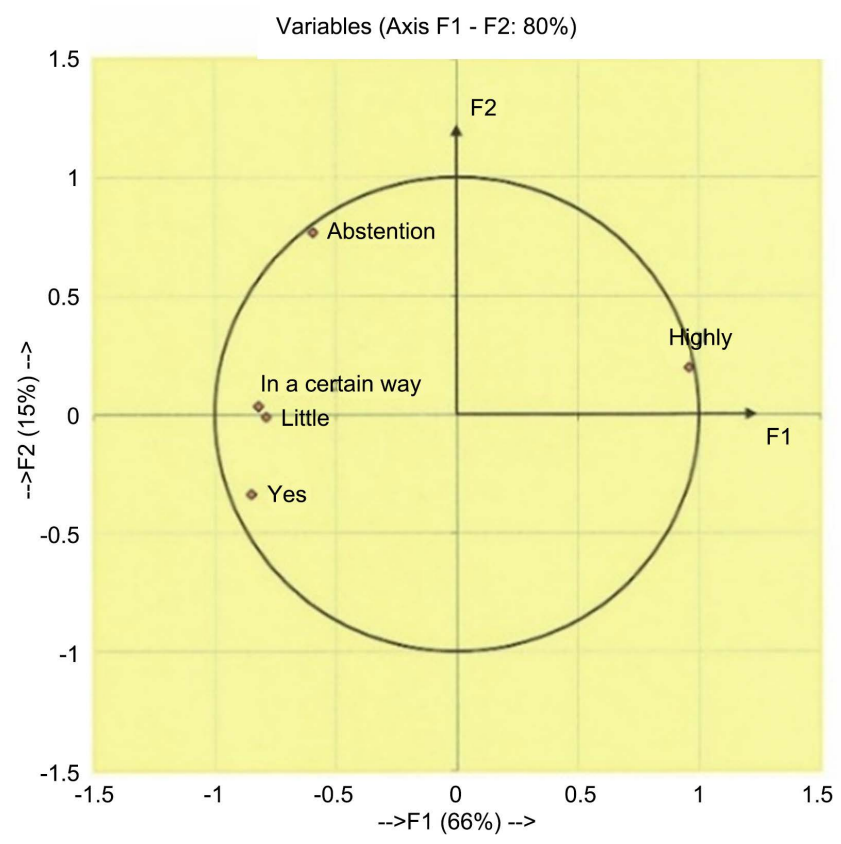

(a) 


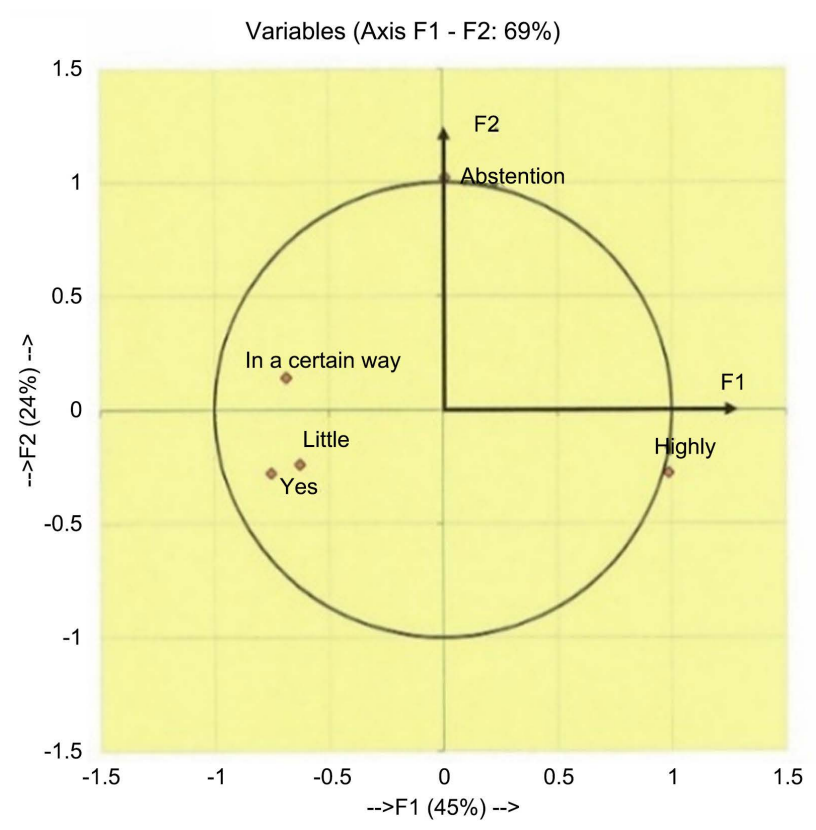

(b)

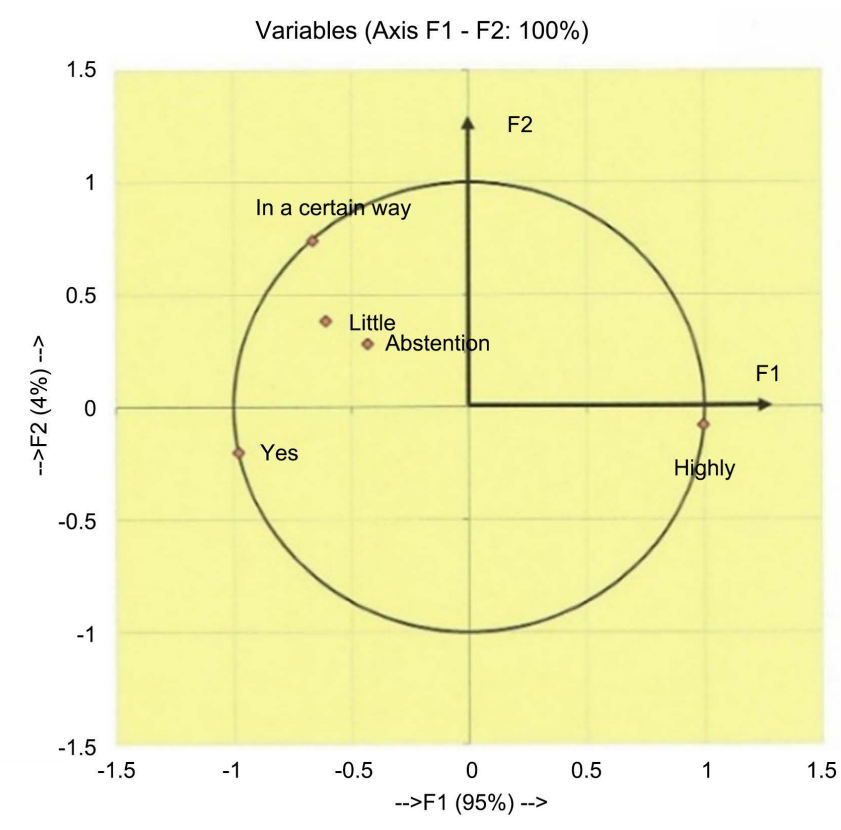

(c)

Figure 1. (a, b, and c) show graphic representations of the two first principal components of each analysis in accordance with the distance used.

Table 2. Significant values for Alpha threshold $=0.05$ (bilateral test).

\begin{tabular}{|c|c|c|c|c|c|c|}
\hline \multirow{2}{*}{ Quality of the course } & \multirow{2}{*}{$\begin{array}{l}\text { Standard } \\
\text { deviation }\end{array}$} & \multicolumn{5}{|c|}{ Pearson's } \\
\hline & & A & 2 & 3 & 4 & 5 \\
\hline A: Abstention & 0.84 & 1.00 & 0.36 & 0.40 & 0.34 & -0.47 \\
\hline 2: Low quality & 0.49 & 0.36 & 1.00 & 0.65 & 0.51 & -0.64 \\
\hline 3: Certain quality & 3.05 & 0.40 & 0.65 & 1.00 & 0.50 & -0.72 \\
\hline 4: Quality & 8.75 & 0.34 & 0.51 & 0.50 & 1.00 & -0.96 \\
\hline \multirow[t]{2}{*}{ 5: High quality } & 11.29 & -0.47 & -0.64 & -0.72 & -0.96 & 1.0 \\
\hline & & \multicolumn{5}{|c|}{ Spearman's } \\
\hline A: Abstention & 0.84 & 1.00 & 0.43 & 0.50 & 0.11 & -0.25 \\
\hline 2: Low quality & 0.49 & 0.43 & 1.00 & 0.68 & 0.47 & -0.59 \\
\hline 3: Certain quality & 3.05 & 0.50 & 0.68 & 1.00 & 0.52 & -0.73 \\
\hline 4: Quality & 8.75 & 0.11 & 0.47 & 0.52 & 1.00 & -0.94 \\
\hline \multirow[t]{2}{*}{ 5: High quality } & 11.29 & -0.25 & -0.59 & -0.73 & -0.94 & 1.0 \\
\hline & & \multicolumn{5}{|c|}{ Spearman's } \\
\hline A: Abstention & 0.84 & 1.00 & -0.28 & 0.06 & -0.34 & -0.38 \\
\hline 2: Low quality & 0.49 & -0.28 & 1.00 & 0.35 & 0.02 & -0.63 \\
\hline 3: Certain quality & 3.05 & 0.06 & 0.35 & 1.00 & 0.31 & -0.52 \\
\hline 4: Quality & 8.75 & -0.34 & 0.02 & 0.31 & 1.00 & -0.84 \\
\hline \multirow[t]{2}{*}{ 5: High quality } & 11.29 & -0.38 & -0.63 & -0.52 & -0.84 & 1.0 \\
\hline & & \multicolumn{5}{|c|}{ Spearman's } \\
\hline
\end{tabular}


Continued

\begin{tabular}{lcccccc}
\hline A: Abstention & 0.84 & 0.70 & 0.15 & 1.03 & 2.52 & -4.40 \\
2: Low quality & Not calculated & 0.15 & 0.24 & 0.97 & 2.17 & -3.53 \\
3: Certain quality & Not calculated & 1.03 & 0.97 & 9.30 & 13.45 & -24.73 \\
4: Quality & 8.75 & 2.52 & 2.17 & 13.45 & 76.59 & -94.73 \\
5: High quality & 11.29 & -4.40 & -3.53 & -24.75 & -94.73 & 127.4 \\
\hline
\end{tabular}

Pearson's, Spearman's, Kendall's and covariance correlation coefficients. The corresponding mean value is given in Table 1, column Estimated.

Data from ACPs does not shed much light on that which the students really answer, since data are not disaggregated. Let us now see only the graphic of the first factorial plane of a Factorial Correspondence Analysis, FCA, carried on data; questionnaire from Annex 2.

Factorial plane groups $25 \%$ of data under analysis; $14 \%$ for $\mathrm{F}_{1}$ and $11 \%$ for $\mathrm{F}_{2}$. Its graphic shape is flat ellipsoid with center slightly to the right from the origin. In addition, there are two conglomerates of quality of course level: one on the upper right with question: Did the teacher promote participation of the students in class? And a second conglomerate on the lower part of the question, opposed to the first one: Does the result of my assessments correspond to the degree of knowledge I acquired? (Figure 2). The contingency table for this type of factorial analysis has been created based on the three natural classes containing the variable abstention, and it must be noticed that the numerical results obtained from FCA, coordinates, their contributions and square cosines of questions and levels of quality of the course are mainly related to questions $1,10,11,12$, and 13, see Annex 3. These questions make the first factor and are opposed to what seems to be a claim from students, namely, the improper clarification of doubts. In addition, these questions are out of the triangular relationship containing most of the questions defining the quality of the course. Interpretation of the second factor is an opposition between participation of the student in class, promoted by the teacher, and the final grade corresponding to the degree of knowledge acquired, around acceptance of clarification of doubts, both in class and through Smartphone. This second factor builds the first factorial plane, Figure 2.

After all the statistical methodology, it is not clear if teaching a course at an engineering level in person exclusively using an ICT promotes and develops among the student's skills and competencies for better learning.

I believe it must be made clear that the questionnaire used in this study to assess the teacher, Annex 3, did not intend to be thorough on the labor control, academic, knowledge, responsibility, and self-efficiency topics. It is only a small collection of the main topics that are significant for the institution in order to assess knowledge (questions 5, 6, 7, 8, 9, 12 and 13), attitude (2, 3, 4 and 11) and performance in the classroom (questions 1, 2, 6, 10) of its academic personnel. Assessment of teachers in the institution has been made for 50 years and, among other things, it is useful to promote academic improvement, productivity and 


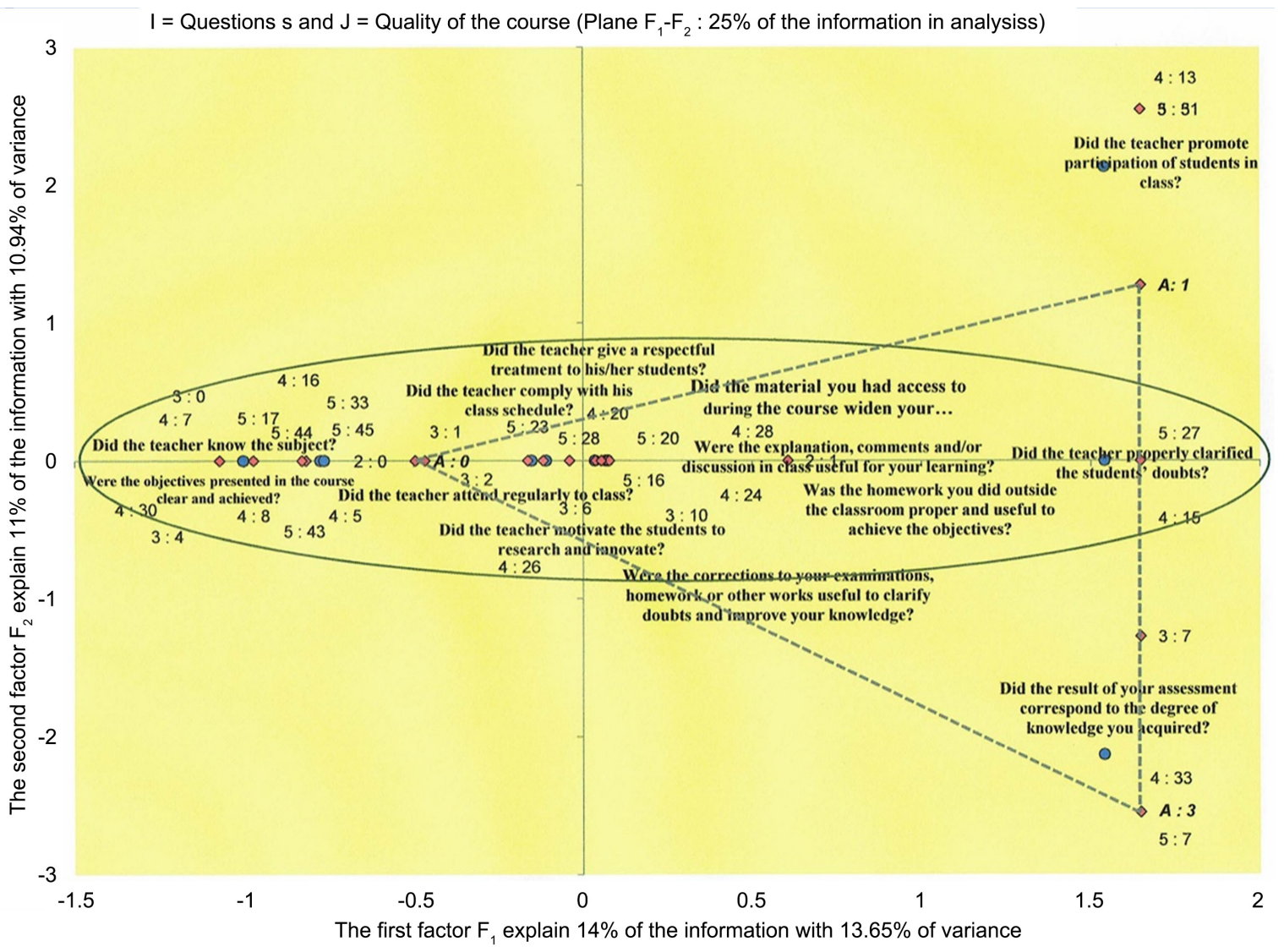

Figure 2. First factorial plane $F_{1} \times F_{2}$.

academic benefits of the personnel. Official academic questionnaires are electronic and compulsory for the student in order to complete the course. Annex 1 and Annex 2 were designed to manage the students' work.

\section{Soliloquy}

It has been written that students improve academically after using ICTs, but the authors do not specify in which way. For me, this is something that must be studies at this level. I have also seen improvement in some students, but in two counterpoised ways. In some students, it is satisfactory since they have demonstrated that, with their classical problems of learning, they are capable of progressing academically using any new technology, but in others, their behavior becomes irrational, since they have succeeded in the challenge and their attitude is irreverent.

The new experience of addicts to ICTs is in the use of robotics, which has improved a lot in the last years, since research groups are using various educational models in which the robot is implied in the learning process. This is feasible thanks to the use of robots that improve the experience of the student and, as it is being currently studied, this may improve the individualized educational process.

Finally, it is worth stating that I have taken and edited video in this type of 
course, where the format, the development and behavior of the students and teacher are recorded.

\section{Conclusions}

It is evident that when a teacher decides to use new technologies in his/her teaching practice, he/she is inevitably facing new challenges in his/her profession. This adaptation process in teaching practice is not easy and not achievable in a short period of time. Therefore, it is important to emphasize the basic idea that planning activities with new technologies should not be carried out spontaneously but should be based on an educational model as has been shown in the case. That is, the activity becomes meaningful pedagogically not for its being carried out, but because it is part of a large process oriented towards the achievement of learning objectives underlying the basic educational model.

It must be mentioned that each student included in this case study used his/her capabilities and knowledge at unusual hours, that is, 1 a.m. or 2 a.m., sharing their work with me or asking me for academic help to solve a specific problem.

ICTs, as any other didactic material or resource, enable the development and practice of various learning methodologies [22]. As part of a non-thorough list of generic learning activities the students have carried out using computing resources, the following may be mentioned:

- To search for, choose and analyze information on the Internet with a specific purpose;

- To acquire competencies and skills, use various technological tools and resources; and

- To know how to use various software.

From the statistical point of view, I may state that the relationship between the abstention and low-quality questions shows low relevance in the correct opinion of the quality of the course, and the conclusion on conformity of low quality of the course is significant, that is, there is a disagreement between the low quality of the course and the correct opinion of the quality of it. The above may also mean that the few students that gave this grade to the course are in an irreverent status, therefore, the questions given regarding the low quality of the course against the large number of positive answers regarding certain quality and high quality of the course are evident.

Questions 1, 10, 11, 12, and 13; see Annex 3, build the first factor and are opposed to what seems to be a claim from a type of students: the improper clarification of doubts by their peers. In addition, these questions are out of the triangular relationship containing most of the questions defining the quality of the course. The interpretation of the second factor is an opposition between participation of the student in class, promoted by the teacher, and the final grade corresponding to the degree of knowledge acquired, around the acceptance of clarification of doubts, both in class and through smartphone. This second factor 
builds the first factorial plane that weakens a course with these features with the purpose to promote among the students the skills and competencies for the development, learning and presentation of topics.

I believe that the smartphone may be considered as an ICT, since, from my point of view, it is a highly portable technology with massive access, but its small screen makes it complicated to use and complicates its didactic application. Finally, while it is not a conclusion, and as I mentioned earlier, I must emphasize that didactic work developed like this is incredibly exhausting both for students and the teacher.

\section{Future Works}

Among the proposals of research to be carried out in the immediate future, there is in the first place an analysis of the controversy between creating or not regulations for the use of smartphones in the classroom. That is, should the rules for academies include specific rules for the use of such electronic devices in class? This kind of discussion seems to be imminent since, probably, the education in the world will become hybrid (in person and distance learning). This topic is fundamental, since it will allow to research-analyze-study the discussion of improper uses of smartphones in the classroom and not to consider them as enemies of teachers. Such researches will allow to specify the pedagogical objectives that imply and to prepare protocols to incorporate such electronic devices in the classroom at $100 \%$.

\section{Acknowledgements}

This paper and part of the research carried out has been possible thanks to the support by the research projects IPN-SIP 20130805and IPN-SIP 20181253.

\section{Conflicts of Interest}

The author declares no conflicts of interest regarding the publication of this paper.

\section{References}

[1] Laudon Kenneth, C., Traver, C.G. and Laudon, J.P. (1994) Information Technology: Concepts and Issues. Course Technology, $352 \mathrm{p}$.

[2] Hardy, I.R. (1996) The Evolution of ARPANET Email. History Thesis, University of California at Berkeley, Berkeley.

[3] IPN México (2003) Un Nuevo Modelo Educativo para el IPN. Materiales para la reforma. Dirección de Publicaciones, Vol. I, Instituto Politécnico Nacional.

[4] Leiner, B.M., Cerf, V.G., Clark, D.D., Kahan, R.E., Kleinrock, L., Lynch, D.C., Postel, J., Robert, L.G. and Stephen, W. (1997) Brief History of the Internet. https://www.internetsociety.org/internet/history-internet/brief-history-internet/

[5] Casanova-del-Angel, F. (2011) La utilización de las TIC's, una propuesta de cambio para el aprendizaje. Décima Conferencia Iberoamericana en Sistemas, Cibernética e Informática, and 8avo Simposium Iberoamericano en Educación, Cibernética e In- 
formática, Orlando, 19-22 July 2011, 171-176.

[6] Casanova-del-Angel, F. (2011) Contribución a la calidad en el proceso enseñanza-aprendizaje en las escuelas superiores en México. 3er Congreso Internacional de Orientación Educativa y Tutoría, Mexicali, 18-21 October 2011, 18-21.

[7] Baran, P. (1994) On Distributed Communication Networks. IEEE Transactions on Communications Systems, 12, 1-9. https://doi.org/10.1109/TCOM.1964.1088883

[8] del Refugio, B.P.M., de los Ángeles, C.P.M., Rosa, C.R.A., Xóchitl, D.R., Heriberto, D.V., Elizabeth, M.V. and Gerardo, M.C. (2005) Somero análisis del nuevo modelo educativo del IPN. Revista Investigación Administrativa, No. 95, 21-37.

[9] Darko-Adjei, N. (2019) The Use and Effect of Smartphones in Students' Learning Activities: Evidence from the University of Ghana, Legon. Library Philosophy and Practice (e-Journal), Article No. 2851.

https://digitalcommons.unl.edu/libphilprac/2851

[10] Kadry, S. and Ghazal, B. (2019) Design and Assessment of Using Smartphone Application in the Classroom to Improve Student's Learning. International Journal of Engineering Pedagogy, 9, 17-34. https://doi.org/10.3991/ijep.v9i2.9764

[11] Silva Calpa, A.C. and Martínez Delgado, D.G. (2017) Influencia del Smartphone en los procesos de aprendizaje y enseñanza. Journal Suma de Negocios, 8, 11-18.

https://doi.org/10.1016/j.sumneg.2017.01.001 https://www.sciencedirect.com/science/article/pii/S2215910X17300010

[12] Organista-Sandoval, J., McAnally-Salas, L. and Lavigne, G. (2021). El teléfono inteligente (smartphone) como herramienta pedagógica. Apertura, 13, 12-22.

[13] Casanova-del-Angel, F. (2013) Games as a Proposal for Change in the Civil Engineering Learning Process. The 2013 International Conference on Frontiers in Education: Computer Science and Computer Engineering, 22-25 July 2013, Las Vegas, 127-132.

[14] Rosas Sánchez, M.E. and Casanova-del-Angel, F. (2016) Como Contribuir al Proceso de Obtención de una Educación de Calidad en el Nivel Superior en México. Sexta Conferencia Iberoamericana de Complejidad, Informática y Cibernética, en el contexto del. The 7 th International Multi-Conferences on Complexity, Informatics, and Cybernetics, Orlando, 8-11 March 2016, 107-112.

[15] Casanova-del-Angel, F. (2015) Hierarchical Cores Case: Use of Technologies in the Higher Education Students. CARME 2015. Correspondence Analysis and Related Methods, Naples, 20-23 September 2015, 26.

[16] Casanova-del-Angel, F. (2012) Terminal Efficiency Analysis of a Postgraduate Degree, Under the Theory of Hierarchical Distances Geometric Structure. The 2012 International Conference on Frontiers in Education: Computer Science \& Computer Engineering, Las Vegas, 16-19 July 2012, 143-147.

[17] Casanova del Angel, F. (2001) Análisis multidimensional de datos. Registro público de derechos de autor núm.

[18] Casanova-del-Angel, F. (2014) Hierarchical Cores Applied to an Analysis of Use of Technologies Level among Higher Education Students in Mexico. Open Journal of Statistics, 4, 837-850. https://doi.org/10.4236/ojs.2014.410079 http://www.scirp.org/journal/Home.aspx?IssueID=5686\#.VL5uqy4YE8Q

[19] Casanova-del-Angel, F. (2002) Bibliography in Statistics to Enhance Research. The 6 th International Conference on Teaching Statistics, Cape Town, 7-12 July 2002, $1-4$.

[20] Casanova-del-Angel, F. (1994) Análisis estadístico del rendimiento académico del 
currículo de licenciatura en ingeniería civil. IV Encuentro de Estadísticos México-Cuba, ICIMAF, ACC. La Habana Cuba, 14-18 February 1994, 14-18.

[21] Casanova-del-Angel, F. (2014) Ludic Teaching of Statistics at a Higher Level: Combinatorial Analysis Case. 7 th International Multi-Conference on Engineering and Technological Innovation, Orlando, 15-18 July 2014, 64-67.

[22] Casanova-del-Angel, F. (2013) Cómo construir una formación profesional basada en nuevas tecnologías de aprendizaje. Décima Segunda Conferencia Iberoamericana en Sistemas, Cibernética e Informática, Orlando, 9-12 July 2013, 176-181. 


\section{Annex}

\section{Annex 1. Format for Grades Given by the Students}

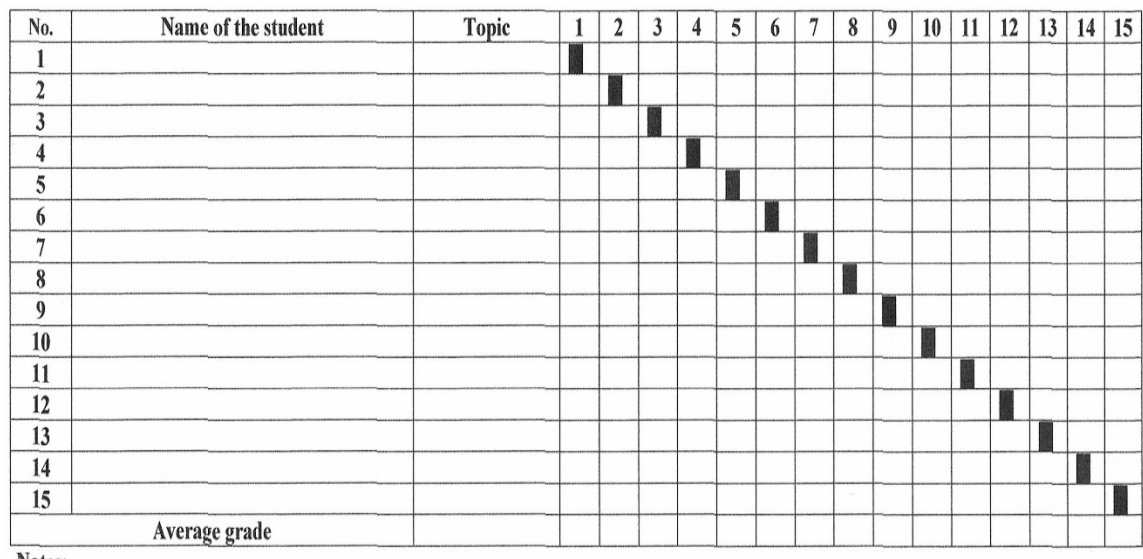

Annex 2. Format to Assess Homework

\begin{tabular}{|c|c|c|c|c|c|}
\hline \multirow{2}{*}{\multicolumn{3}{|c|}{ Record of the topic's homework }} & \multirow{2}{*}{\multicolumn{2}{|c|}{$\begin{array}{l}\text { The grade will be given as follows: } \\
\mathrm{A} \downarrow \text { will be given to the student who has at least one exercise solved correctly } \\
\text { and a } \mathbf{X} \text { if he/she did not answer one or more exercises or hose are incorrectly } \\
\text { solved }\end{array}$}} & \multirow{2}{*}{$\begin{array}{l}\text { Number of } \\
\text { exercises: }\end{array}$} \\
\hline & & & & & \\
\hline Name of student & $\begin{array}{c}\text { Number of } \\
\text { correct } \\
\text { exercises }\end{array}$ & $\sqrt{ }$ & $\mathrm{X}$ & \multicolumn{2}{|l|}{ Notes } \\
\hline & & & & & \\
\hline & & & & & \\
\hline & & & & & \\
\hline & & & & & \\
\hline & & & & & \\
\hline & & & & & \\
\hline & & & & & \\
\hline & & & & & \\
\hline & & & & & \\
\hline & & & & & \\
\hline & & & & & \\
\hline & & & & & \\
\hline & & & & & \\
\hline & & & & & \\
\hline & & & & & \\
\hline
\end{tabular}




\section{Annex 3. Questionnaire to Assess Teachers}

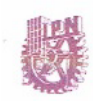

Civil Engineering
Higher School of Engineering and Architecture, UP ALM National Polytechnic Institute

Notes:

- The purpose of this questionnaire is to gather your opinion regarding the quality of the course you have received and act to improve the teaching practice. Answering this questionnaire is voluntary.

- Please, answer sincerely the following questions, crossing the symbol corresponding to your answer.

- To answer, consider that:

ABSTENTION (Without grounds to answer): 1) NO; 2) LITTLE; 3) IN A CERTAIN WAY; 4) YES; 5) HIGHLY

COURSE:

DATE:

TEACHER:

\begin{tabular}{|l|l|l|l|l|l|l|l|}
\hline No. & Question & $\mathbf{A}$ & $\mathbf{1}$ & $\mathbf{2}$ & $\mathbf{3}$ & $\mathbf{4}$ & $\mathbf{5}$ \\
\hline
\end{tabular}

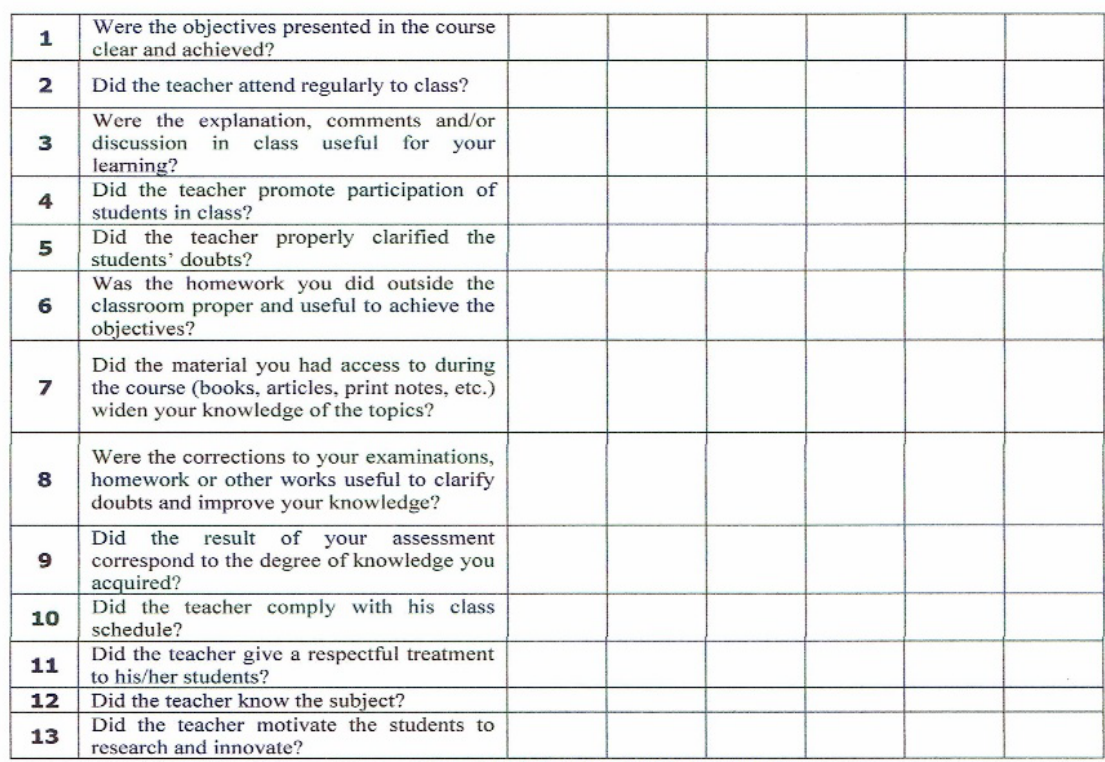

Answer freely the following three questions:

What did you like about the course?

What did you not like about the course?

What would you change about the course? 